OPEN ACCESS

Edited by:

Thomas Deller,

Goethe University Frankfurt, Germany

Reviewed by:

Stefan Lichtenthaler,

DZNE - German Center for Neurodegenerative Diseases,

Germany

Michael R. Kreutz,

Leibniz-Institute for Neurobiology,

Germany

${ }^{*}$ Correspondence:

Klemens Wild

klemens.wild@bzh.uni-heidelberg.de

Stefan Kins

s.kins@biologie.uni-kl.de

Received: 25 October 2016 Accepted: 16 January 2017 Published: 31 January 2017

Citation:

Wild K, August A, Pietrzik CU and Kins S (2017) Structure and Synaptic

Function of Metal Binding to the

Amyloid Precursor Protein and its

Proteolytic Fragments.

Front. Mol. Neurosci. 10:21.

doi: 10.3389/fnmol.2017.00021

\section{Structure and Synaptic Function of Metal Binding to the Amyloid Precursor Protein and its Proteolytic Fragments}

\author{
Klemens Wild ${ }^{1 *}$, Alexander August ${ }^{2}$, Claus U. Pietrzik ${ }^{3}$ and Stefan Kins ${ }^{2 *}$ \\ ${ }^{1}$ Heidelberg University Biochemistry Center (BZH), University of Heidelberg, Heidelberg, Germany, ${ }^{2}$ Division of Human \\ Biology and Human Genetics, Technical University of Kaiserslautern, Kaiserslautern, Germany, ${ }^{3}$ Institute for \\ Pathobiochemistry, University Medical Center of the Johannes Gutenberg-University Mainz, Mainz, Germany
}

Alzheimer's disease (AD) is ultimately linked to the amyloid precursor protein (APP). However, current research reveals an important synaptic function of APP and APP-like proteins (APLP1 and 2). In this context various neurotrophic and neuroprotective functions have been reported for the APP proteolytic fragments SAPP $\alpha, \operatorname{SAPP} \beta$ and the monomeric amyloid-beta peptide (A $\beta$ ). APP is a metalloprotein and binds copper and zinc ions. Synaptic activity correlates with a release of these ions into the synaptic cleft and dysregulation of their homeostasis is linked to different neurodegenerative diseases. Metal binding to APP or its fragments affects its structure and its proteolytic cleavage and therefore its physiological function at the synapse. Here, we summarize the current data supporting this hypothesis and provide a model of how these different mechanisms might be intertwined with each other.

\section{Keywords: amyloid precursor protein (APP), zinc, copper, synaptic transmission, Alzheimer's disease}

\section{INTRODUCTION}

Alzheimer's disease (AD) is a fatal neurodegenerative disorder and a severe burden of our aging societies (Schaller et al., 2015). One pathological hallmark of $\mathrm{AD}$ is the formation of senile plaques deposited in the brain concomitant with a massive decline of neuronal mass and therewith of memory and cognitive abilities (Selkoe and Hardy, 2016). On the molecular level, the amyloid precursor protein (APP) is fundamental to the pathology as the plaques predominantly consist of its proteolytic breakdown product, which is the neurotoxic amyloid-beta peptide (A $\beta$; Selkoe, 2011; Haass et al., 2012). APP and the paralogous APP-like proteins (APLP1 and 2) are expressed in various tissues (APLP1 only in the brain) and in alternative splice forms (Walsh et al., 2007; Müller and Zheng, 2012) and are concentrated in the synapses of neurons. They are single-span type I transmembrane proteins with a large extracellular domain (ectodomain) and a short cytoplasmic tail APP intracellular domain (AICD; Coburger et al., 2014). APP is a prime example for ectodomain shedding by $\alpha$-, $\beta$-, or $\gamma$-secretases and for regulated intramembrane proteolysis (RIP) by the $\gamma$-secretase complex (Thinakaran and Koo, 2008; Haass et al., 2012). In the first step, the majority of the extracellular domain is shed off at distinct sites within the juxtamembraneous domain by different proteases, involving ADAM10 and BACE. The resulting extracellular cleavage products are released in form of soluble fragments, designated according to the cleavage 
site as $\operatorname{sAPP} \alpha$ and $\mathrm{sAPP} \beta$, respectively (Brunholz et al., 2012). More recently, an additional more N-terminally located $\eta$-cleavage site was described, possibly mediated by cleavage of MT5-MMP (Willem et al., 2015). This causes an even more complex picture of APP processing, including besides sAPP $\eta$ different extracellularly released fragments, such as $A \eta-\alpha$ or A $\eta-\beta$ peptides. In fact, accumulating evidence suggests that the APP processing is likely even more complex, as additional cleavage sites within the $A \beta$ domain by e.g., Meprin $\beta$ have been described (Bien et al., 2012). However, the different residual carboxyl-terminal fragments (CTFs) are subsequently cleaved by the $\gamma$-secretase complex, which causes in case of preceded $\mathrm{BACE} 1$ shedding release of various $\mathrm{A} \beta$ peptides (A $\beta 1-36$ to $A \beta 1-43$ ) and the AICD (Steiner et al., 2008). The regulation of cleavage is a key event for both physiological and pathological processes, whereby the pathophysiological relevance of all the different peptides is yet not well understood, and depends on the localization of APP, on post-translational modifications, and on its oligomerization state (Kienlen-Campard et al., 2008; Eggert et al., 2009; Haass et al., 2012; Muresan and Ladescu Muresan, 2015; Winkler et al., 2015). APP is in equilibrium between monomeric and dimeric species (Soba et al., 2005; Isbert et al., 2012) and underlies a rapid turnover from the cell surface into endosomal compartments, the presumed major place of $\mathrm{A} \beta$ generation (Thinakaran and Koo, 2008; Haass et al., 2012).

APP localization, oligomerization state and processing are influenced by direct binding to copper and zinc ions (Acevedo et al., 2011; Baumkötter et al., 2014; Mayer et al., 2014) and dysregulation of copper and zinc homeostasis are an apparent feature of neurodegenerative diseases, including AD. However, as APP binds copper and zinc with affinities in the nano and micro molar range, respectively, and as local concentrations of copper and zinc can vary quiet a lot, it appears reasonable that metal binding occurs only under certain pathophysiological conditions. Here, we summarize recent advances in the molecular details of copper and zinc binding to APP and their potential impact on APP processing and their potential role in the pathological as well as in the physiological context.

\section{APP AND ITS FRAGMENTS AS METALLOPROTEINS}

APP is a multi-domain membrane protein with a single transmembrane domain (TMD) and several unstructured regions (APP numbering in the following corresponds to APP770, UniProtKB: P05067; Figure 1). The large extracellular ectodomain (residues 18-699) is divided into the $\mathrm{N}$-terminal growth factor-like domain (GFLD, 18-123), the copper-binding domain (CuBD, 124-189), an unstructured acidic domain (AcD, 190-289), a Kunitz-type protease inhibitor (KPI) domain with an Ox2 region (290-364, not present in neuronal APP695 splice form), the E2 domain (365-575), and the juxtamembrane region (JMR, 576-699). GFLD and CuBD form a structural unit termed E1 domain. The JMR harbors the sites for secretase cleavage during the process of ectodomain shedding.

Metal binding is well documented to APP and to A $\beta$ peptides (Hesse et al., 1994; Talmard et al., 2007; Kong et al., 2008; Dahms et al., 2012; Baumkötter et al., 2014). Copper binding to APP has been first structurally characterized for the CuBD (Barnham et al., 2003; Kong et al., 2007). Copper (II) binds with high affinity $\left(K_{\mathrm{D}}\right.$ of $10 \mathrm{nM}$; note: binding constants to copper and zinc ions strongly depend on the applied method and conditions and values have to be evaluated critically) in a slightly distorted square pyramidal geometry (a type 2 non-blue site) to three protein ligands (His147, His151 and Tyr168) and two water molecules (Figure 2A; Kong et al., 2008). The distorted type 2 geometry is consistent with an observed redox-activity of APP, and CuBD was found to also bind copper (I) (with one water ligand lost) although no conformational change within the protein could be detected. Interestingly, although not interpreted in the original articles, a nearby disulfide bridge (Cys144Cys174) is partly reduced in the high-resolution structures. The mechanism of how copper-binding to the CuBD could

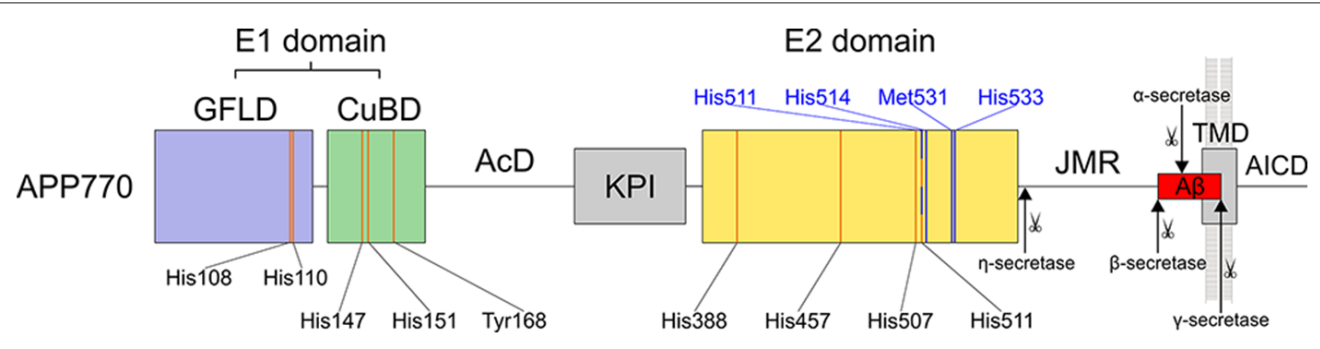

FIGURE 1 | Schematic overview of amyloid precursor protein (APP770). The domain architecture is given with residues involved in metal binding and cleavage sites of various secretases. The E1 domain contains two copper binding sites (orange lines) with clustered residues (four histidines and one tyrosine), one in the growth factor like domain (GFLD, blue) and one in the copper binding domain (CuBD, green). The E1 domain is followed by an acidic domain (AcD) and a Kunitz protease inhibitor (KPI) domain (gray). The E2 domain (yellow) binds copper via four histidine residues (orange lines). Zinc binding involves three residues of the copper binding site (His457, His507 and His511, while His388 is replaced by a water molecule). The residues corresponding to the recently identified zinc binding site in APLP1 are highlighted in blue. Three of four histidines are conserved while His450 is replaced by Met531 in APP770. The juxtamembrane region (JMR) and transmembrane domain (TMD, gray) harbor the A $\beta$ region (red). After $\beta$-secretase cleavage at Met671 and further $\gamma$-secretase cleavage at various sites within the $\mathrm{TMD}, \mathrm{A} \beta$ is liberated into the extracellular space, whereas the APP intracellular domain (AICD) is released into the cytosol. Cleavage by $\alpha$-secretases occurs within the $A \beta$ region at Lys687. Additionally, $\eta$-secretase cleaves the ectodomain at position Asn579. 

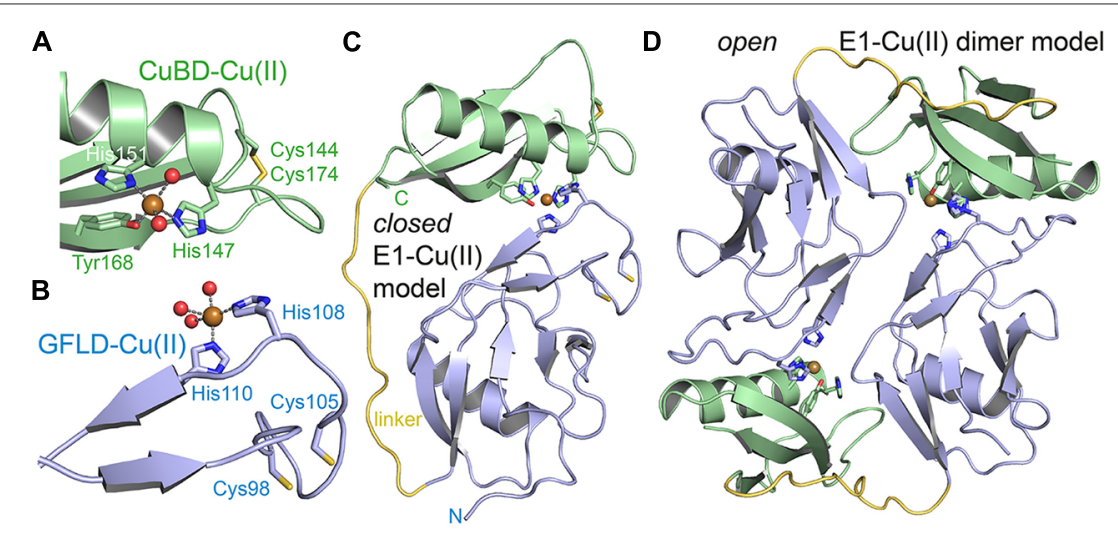

FIGURE 2 | Metal binding to the E1 domain. (A) The CuBD of human APP bound to copper (II) (PDB code: 2fk1). Copper is coordinated by three protein ligands and two water molecules. The shown disulfide bridge is partially reduced. (B) The GFLD of human APP bound to copper (II) (PDB code: 4jfn). Copper is coordinated in the same geometry as in the CuBD. Two ligand sites are occupied by protein and three sites by a crystal contact (aspartate) replacing three water molecules. The inferred hydrated state in solution is shown. The disulfide bridge adjacent to the copper binding site is reduced. (C) A putative "closed" E1 domain by the intramolecular combination of the two ligand bindings sites of GFLD and CUBD and modeling of a flexible linker (yellow). (D) The respective "open" E1 domain by intermolecular combination of the binding sites. The monomeric E1 domain corresponds to PDB code 4pwq.

decrease $\mathrm{A} \beta$ production as described in $\mathrm{CHO}$ cells (Borchardt et al., 1999) and various mouse studies (Bayer et al., 2003) however remained enigmatic. Specific binding of zinc to two C-terminal cysteines (Cys186 and Cys187) within the CuBD has also been reported (Bush et al., 1993). However, data had been acquired with tryptic and synthetic peptides and in available structures the two cysteines are not available for zinc coordination. Crystallographic analyses of the $\mathrm{CuBD}$ with bound zinc would help to clarify this point and would build the basis for follow-up studies, addressing the impact of zinc binding on APP pathophysiology.

Recently, we reported specific copper binding to the $\mathrm{N}$-terminal GFLD (Figure 2B; Baumkötter et al., 2014). Here, copper (II) was found to adopt the same ligand geometry with however two protein ligands (His108 and His110) in a flexible hairpin loop also involved in Heparin binding and putatively three water ligands (mimicked in the crystal by an aspartate of a symmetry contact). Binding affinity as determined by isothermal titration calorimetry (ITC) is in the low nanomolar range ( $K_{\mathrm{D}}$ of $28 \mathrm{nM}$ ) almost as high as to CuBD. Copperbinding to the GFLD again correlates with the reduction of a neighboring disulfide bridge (Cys98-Cys105) pointing to redoxactivity also of this site. Furthermore, the match of geometry and functionality is suggestive for a complementation of the two copper-binding sites by either a conformational change within the E1 domain into a "closed" conformation (Figure 2C) or by dimerization of two "open" E1 domains in trans (Figure 2D). In line, conformational flexibility within the E1 domain has been validated recently (Hoefgen et al., 2015). In contrast to the CuBD and E2 domains, no binding to the GFLD could be detected for zinc ions (Baumkötter et al., 2014).

The E2 domain (Dahms et al., 2012), which like E1 binds strongly to copper $\left(K_{\mathrm{D}}\right.$ of $\left.13 \mathrm{nM}\right)$ and with low affinity to zinc $\left(K_{\mathrm{D}}\right.$ of $3.9 \mu \mathrm{M}$; with some uncertainties of the ITC measurements) harbors two or three different metal binding sites, here designated as M1-3 (also see Table 1). Both metals bind to the same evolutionary conserved site (denoted as M1) within the APP family and due to the more than 100 times lower affinity, zinc (II) cannot compete for copper (II) binding in vitro. In X-ray structures of the metal-bound E2 domain the M1 site is found central to the coiled-coil like fold and consists of four histidines (His388, His457, His507 and His511 for APP770 numbering) spread on three helices $(\alpha B, \alpha C$ and $\alpha D$; Figures 3A,B; Dahms et al., 2012). The ligand coordination has been described as tetrahedrally-distorted square planar geometry (although a fifth ligand is missing here compared to the E1 copper binding sites). Notably, in contrast to the GFLD and CuBD, no redox-activity has been observed for the M1 site. The central location of the M1 site enables a metal dependent conformational switch within the E2 domain with a $12^{\circ}$ bending of the helical rod (Figure 3C) and bending correlates with an increased rigidity and thermostability of the E2 domain.

Copper binding to the E2 domain was reported to stimulate heparin binding, which might be of physiological importance by modulating APP binding to the extracellular matrix during brain development (Dienemann et al., 2015). However, in an X-ray structure of dimeric human APLP1 E2 domain bound to a heparin-hexasaccharide, the M1 site is destroyed and the four histidines are involved in carbohydrate binding instead (Lee et al., 2011). Here, the E2 domain is bent in an orthogonal direction by $13^{\circ}$ due to dimer formation that allows the accommodation of the ligand in the dimer interface in a 2:1 protein to ligand ratio (Figure 3D).

Binding to the M2 site within the E2 domain has been analyzed by competitive cadmium displacement studies similar to analysis of M1 (Dahms et al., 2012). Thereby, cadmium was only partially replaced by zinc, but not by copper. However, no further functional studies validated its functional or structural relevance yet. 
TABLE 1 | Metal binding properties of amyloid precursor protein (APP)/APP-like proteins (APLPs).

\begin{tabular}{|c|c|c|c|c|c|c|c|c|c|c|c|}
\hline & & \multicolumn{7}{|c|}{ Metal binding site properties } & $\begin{array}{l}\text { Alteration in } \\
\text { structure }\end{array}$ & $\begin{array}{l}\text { Validated by } \\
\text { mutations }\end{array}$ & $\begin{array}{l}\text { Functional } \\
\text { implications }\end{array}$ \\
\hline \multirow[t]{2}{*}{ E1 } & GFLD & $\begin{array}{l}\mathrm{H} 108 \\
\mathrm{H} 110\end{array}$ & $\begin{array}{l}\mathrm{H} 130^{\circ} \\
\mathrm{H} 132\end{array}$ & - & $\checkmark$ & $x$ & $\begin{array}{c}\text { Yes } \\
K_{\mathrm{D}}: 28 \mathrm{nM}^{1} \\
\text { ratio: } 1: 1^{1}\end{array}$ & Yes $^{1}$ & $\begin{array}{l}\text { minor; reduction of } \\
\text { disulfide bridge in } \\
\qquad \operatorname{LBL}^{1}\end{array}$ & $\begin{array}{l}\text { Yes (ITC, Co-IP, } \\
\text { cellular assay) })^{1}\end{array}$ & $\begin{array}{l}\text { Cu stimulates cis } \\
\text { and trans directed } \\
\text { dimerization }{ }^{1}\end{array}$ \\
\hline & CuBD & $\begin{array}{l}\mathrm{H} 147 \\
\mathrm{H} 151 \\
\mathrm{Y} 168\end{array}$ & $\begin{array}{c}- \\
\mathrm{H} 174 \\
-\end{array}$ & $\begin{array}{l}\mathrm{H} 163 \\
\mathrm{H} 167 \\
\text { Y184 }\end{array}$ & $\checkmark$ & $\times$ & $\begin{array}{c}\text { Yes } \\
K_{\mathrm{D}}: 10 \mathrm{nM}^{2} \\
\text { ratio: } 1: 1^{1}\end{array}$ & $Y_{e s}{ }^{3}$ & no change & & \\
\hline E2 & M1 & $\begin{array}{l}\text { H388 } \\
\text { H457 } \\
\text { H507 } \\
\text { H511 } \\
\text { E462 } \\
\text { D504 } \\
\text { H533 }\end{array}$ & $\begin{array}{c}\mathrm{H} 307 \\
\mathrm{H} 376 \\
\mathrm{H} 426 \\
\mathrm{H} 430 \\
- \\
- \\
\mathrm{H} 452\end{array}$ & $\begin{array}{l}\text { H387 } \\
\text { H456 } \\
\text { H506 } \\
\text { H510 } \\
\text { E461 } \\
\text { D503 } \\
\text { H532 }\end{array}$ & $\checkmark$ & $\checkmark$ & $\begin{array}{c}\text { Yes } \\
\text { Cu: } K_{\mathrm{D}}: 13 \mathrm{nM} \\
\text { ratio: } 1: 1 \\
\text { Zn: } K_{\mathrm{D}}=4 \mu \mathrm{M} \\
\text { ratio: } 1: 1^{4}\end{array}$ & Yes $^{4}$ & $\begin{array}{l}\text { Distinct changes, } \\
\text { bending of } \\
\mathrm{N} \text {-terminal coiled } \\
\text { coil by } 12^{\circ 4}\end{array}$ & Yes $(\mathrm{ITC})^{5}$ & $\begin{array}{c}\text { Cu and } \mathrm{Zn} \\
\text { stimulate binding of } \\
\text { heparin }{ }^{5} \text {, } \\
\text { involvement of M1, } \\
\text { M2 is unclear }\end{array}$ \\
\hline
\end{tabular}

${ }^{a}$ Isothermal titration calorimetry; ${ }^{b}$ X-ray crystallography; ${ }^{c}$ amino acids indicated in gray represent conserved positions w/o experimental data validating copper or zinc binding; ${ }^{d}$ reported APLP1 specific Zn binding site, here designated as M3 site. ${ }^{1}$ Baumkötter et al. (2014), ${ }^{2}$ Hesse et al. (1994), ${ }^{3}$ Kong et al. (2007), ${ }^{4}$ Dahms et al. (2012), ${ }^{5}$ Dienemann et al. (2015) and ${ }^{6}$ Mayer et al. (2014)
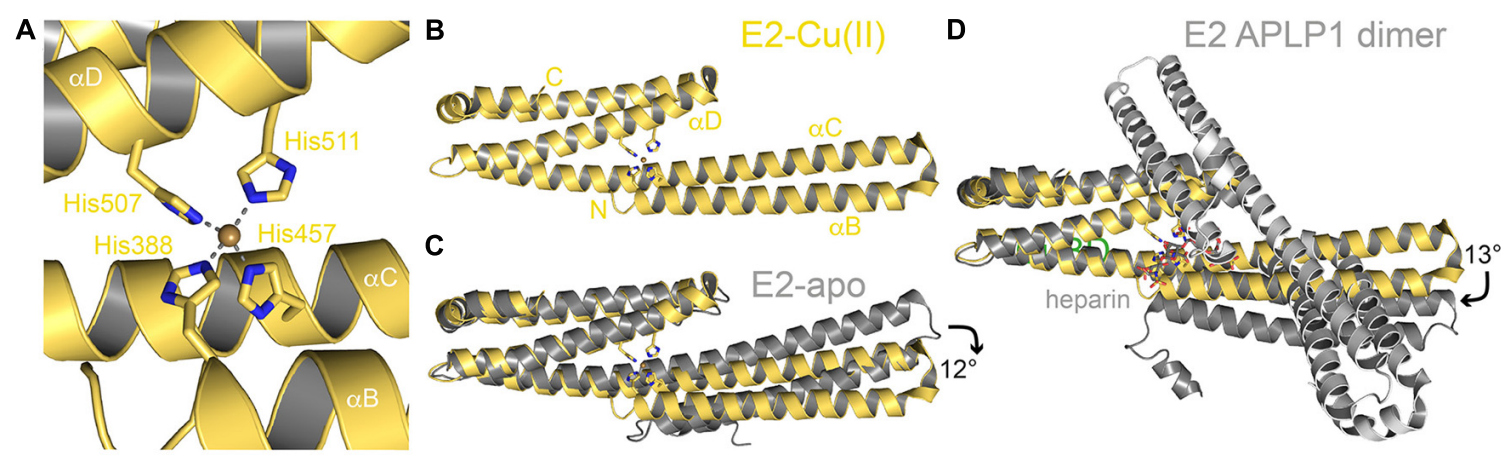

FIGURE 3 | Metal binding to the E2 domain. (A) The copper (II) binding site in the center of the coiled-coil like human E2 domain (PDB code: 3UMK). The four histidine ligands are spread on three different helices. (B) Structure of the complete human E2 domain bound to copper (II). (C) Superposition of E2-Cu(II) with the respective apo form (PDB code: 3NYJ) highlighting the metal induced conformational change. (D) Superposition of E2-Cu(II) with a dimeric APLP1 E2 domain in complex with a heparin hexa-saccharide (PDB code: 3qmk). Heparin binds in a 1:2 molar ratio and occupies the copper (II) binding site.

Two other more recent studies suggested a zinc binding site in the APLP1 E2 domain (between M1 and M2 of APP E2: APLP1 residues His430, His433, His450 and His452) to regulate homo- and hetero-dimerization with APP and APLP2 (Mayer et al., 2014, 2016). Notably, only three of the four histidine residues involved in binding are conserved in APP and APLP2 (Table 1). However, as mutations of single histidine residues only had a minor impact on APLP1 cell adhesion features, it appears reasonable to postulate that binding of zinc to the $M 3$ site might affect APP and APLP2 function in a similar manner. Moreover, specific dimerization implies complementation of metal coordination in trans, which would require a different dimerization as observed in the X-ray structure with heparin.
Such zinc mediated dimerization was observed in a crystal contact of another recent APLP1 E2 structure bound to a heparin dodecasaccharide (Dahms et al., 2015), which however, was mediated again by other surface exposed histidines. Therefore, the structural and physiological consequences of copper and zinc binding to the E2 domain appear still highly controversial and need further investigations.

Since copper and zinc binding to APP is predominantly mediated by histidine and due to $\mathrm{pKa}$ values of this amino acid, the interaction of APP with copper and zinc is impossible under acidic conditions. APP is trafficked through the secretory pathway to the cell surface up to endosomes and lysosomes. Thereby it passes cell compartments with different $\mathrm{pH}$ values. 


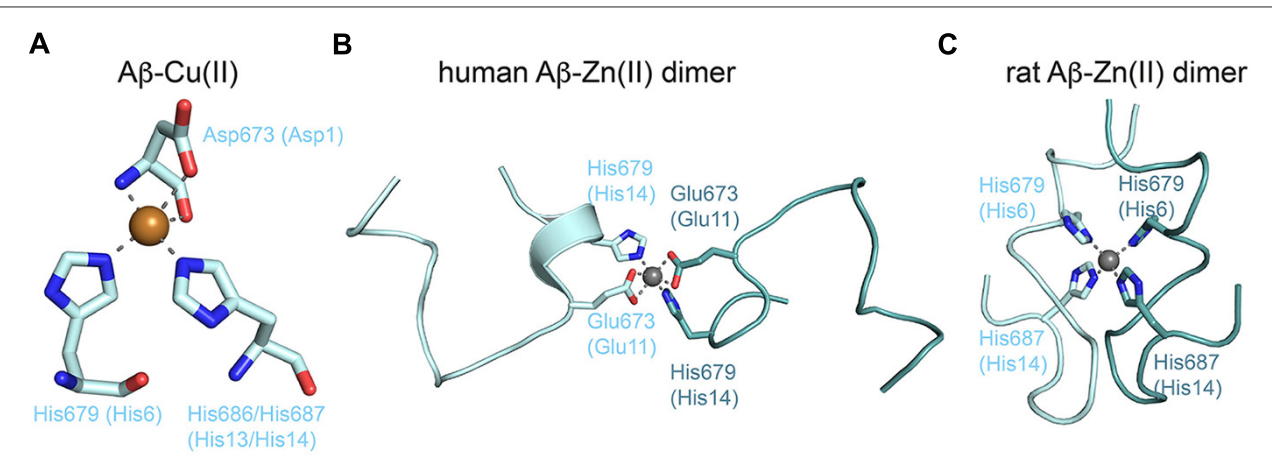

FIGURE 4 | Metal binding to the A $\boldsymbol{\beta}$ peptide. (A) The proposed copper (II) coordination by the $\mathrm{N}$-terminus of A $\beta$ and two histidines. The model corresponds to copper (II) coordination found in the crystal structure of GFLD-Cu(II) with the aspartate originating from a crystal contact (PDB code: 4jfn). (B) NMR structure of dimeric human A $(1-16)$ bound to zinc (II) (PDB code: $2 \mathrm{mgt})$. The zinc ion mediates dimerization via coordination of equivalent residues. (C) NMR structure of dimeric rat $A \beta(1-16)$ bound to zinc (II) (PDB code: 2 li9). Dimerization via the zinc ion is different and highlights the conformational flexibility of $A \beta$ peptides.

The $\mathrm{pH}$ of the ER is near neutral, while the downstream compartments (cis-and trans-Golgi, secretory vesicles) become progressively more acidic down to $\mathrm{pH} 6$ in the trans-Golgi and $<5$ in lysosomes (Casey et al., 2010). Thus, it is likely that APP binding to copper and zinc varies between different subcellular compartments, possibly altering its structure and binding properties. In line with this, it was reported that APP can adopt different conformations depending on $\mathrm{pH}$ (Hoefgen et al., 2015). Interestingly, the altered structure at acidic $\mathrm{pH}$ is stabilized by hydrogen bonds involving His147 and Tyr168 in the $\mathrm{CuBD}$ that mediate copper binding under neutral $\mathrm{pH}$ conditions.

Most attention has been given to copper and zinc binding to $A \beta$ peptides due to the direct influence on pathological processes and metal accumulation (millimolar range) in the amyloid plaques (for review see Tõugu et al., 2011; Tiiman et al., 2013). From a structural viewpoint, the peptide-ligand complexes are difficult to tackle, as both metals rapidly precipitate $A \beta$ and induce a multitude of $A \beta$ conformations and oligomeric assemblies. Furthermore, $A \beta$ conformations strongly depend on the conditions (e.g., $\mathrm{pH}$ and solvent) used for structure determination. The role of metal ions in the self-assembly of $\mathrm{A} \beta$ has been reviewed in detail recently (Faller et al., 2013). In consensus, copper and zinc bind to the $\mathrm{N}$-terminus of $A \beta(1-16$; numbering for $A \beta$-peptide only) in a 1:1 ratio mostly involving the aspartate and alanine at the very $\mathrm{N}$-terminus (Asp672 or Asp1 in $A \beta$ nomenclature, and Ala673), glutamate 11, and various histidines (His6, His13 and His14). Furthermore, redox-active copper is able to induce reactive oxygen species (ROS) that lead e.g., to aggregation-prone cross-linked $A \beta$ dimers by oxidization of Tyr10 (Smith et al., 2007). Respective residues 1-10 are missing in APLP1 and also APLP2 has a two-residue deletion including His6. Affinities for copper vary significantly between attomolar and micromolar values, although careful analyses suggest values in the range of 30-60 nM (Tõugu et al., 2011; Tiiman et al., 2013). No X-ray or NMR structure has been reported for an $A \beta$-copper complex. At a physiological $\mathrm{pH}$ of 7.4 a square-pyramidal coordination is assumed including Asp1 and His6 and His13 or His14
(Faller et al., 2013). Interestingly, this coordination is exactly as found for the X-ray structure of the GFLD-Cu(II) complex, which might therefore be regarded as first atomic model of an $\mathrm{A} \beta$-Cu(II) complex (Figure 4A). Ligands might originate from the same or different $A \beta$ peptides, which reflects the ability of copper (II) to bind to all forms of monomeric, fibrillary and non-fibrillary $A \beta$ species. Zinc binds to the same site as copper, but binding is again weaker with affinities in the lower micromolar range. The commonly accepted coordination includes Asp1, Glu11 and the three histidines. Zinc immediately precipitates $A \beta$ and NMR structures are deposited only for zinc-mediated dimeric $A \beta$-zinc (II) species of a mutant human $A \beta(1-16)$ and rat $A \beta(1-16)$ revealing part of this coordination and different dimerization patterns (Figures 4B,C). Aggregation increases the affinity of $A \beta$ for copper and zinc leading to the apparent high concentrations in the amyloids. However, the structural understanding of this process is just at the beginning despite all efforts taken.

In summary, the biometals copper and zinc bind to different folded regions of the APP ectodomain and to various $A B$ species. Affinities for all sites are about 100 times higher for copper, which challenges the idea of zinc binding to APP in the synaptic cleft despite its excess. In all complexes the metals seem to be involved in diverse conformational changes of APP and APLP1 as well as APLP2, inducing dimerization or oligomerization in different ways and thus might influence specific physiological and pathological processes.

\section{THE ROLE OF COPPER AND ZINC IONS IN ALZHEIMER'S DISEASE}

\section{Zinc and Alzheimer's Disease}

Sustained elevation of zinc levels are detrimental for neurons and have therefore been implicated in $\mathrm{AD}$ pathogenesis (Koh et al., 1996). A multitude of studies have analyzed overall zinc levels within $\mathrm{AD}$ vs. control brains with rather inconsistent outcome (Ayton et al., 2013). In consensus, however, it has been clearly 
demonstrated that zinc levels are increased in amyloid plaques of AD patients (Bush et al., 1994c). The elevated zinc levels concern only a small fraction of the total cortical volume, and the total tissue zinc concentrations only rise during advanced pathology (Religa et al., 2006). Closer analysis revealed zinc binding to the residues $6-28$ of the $\mathrm{A} \beta$ peptide (Bush et al., 1993, 1994a,b,c), where zinc ions may bind to histidines 6, 13 and 14 (Damante et al., 2009) as described above. Binding of zinc ions induces rapid precipitation of $A \beta$ into insoluble aggregates in humans. However, since the rat and mouse $A \beta$ sequences differ from the human $A \beta$ sequence in three amino acids, differences in the affinity for zinc binding may explain why mice and rats do not develop amyloid pathology (Bush et al., 1994c). Zinc is released by glutamatergic fibers in the cortex and hippocampus where the synaptic vesicle located zinc-transporter 3 (ZnT3) loads the metal into synaptic vesicles (Frederickson et al., 2000). In addition to the increased zinc concentrations in amyloid plaques the expression of ZnT3 is closely associated to $A \beta$ deposition. Ten different zinc-transporters have been identified with ZnT3 showing its highest expression within the brain (Palmiter et al., 1996; Huang and Tepaamorndech, 2013). Low ZnT3 expression reduces interstitial (Lee J.-Y. et al., 2002) and vessel-wall (Friedlich et al., 2004) amyloid but increases the levels of soluble $A \beta$ in the brains of the APP transgenic x ZnT3 KO mice (Lee J.-Y. et al., 2002). Zinc does not only affect $\mathrm{A} \beta$ aggregation but also influences APP processing and function. APP processing and subsequent $A \beta$ generation is dependent on ADAM10 activity. ADAM10 requires zinc binding for proteolysis and therefore subtle changes in ADAM10 activity influence $A \beta$ production (Lammich et al., 1999).

\section{Copper and Alzheimer's Disease}

In healthy brain tissue the total copper levels have been reported to increase from youth to adulthood followed by a constant decrease during aging (Maynard et al., 2002). Aged but healthy brain tissue contains approximately $80 \mu \mathrm{M}$ copper, whereas copper levels are decreased by approx. 30\%-40\% in affected brain regions of AD patients (Deibel et al., 1996; Adlard and Bush, 2006; Religa et al., 2006; Magaki et al., 2007). In contrast, copper levels (and zinc levels) are enriched in extracellular amyloid plaques (Lovell et al., 1998; Dong et al., 2003; Miller et al., 2006; Leskovjan et al., 2009). Thus, either elevated levels of copper directly associated with the $A \beta$ peptide or decreased levels of copper in amyloid plaques surrounding brain tissue might affect the course of AD. Copper binds with high affinity to $A \beta$ and promotes its oligomerization and neurotoxicity (Atwood et al., 1998, 2004; Huang et al., 1999; Masters and Selkoe, 2012). Moreover, cellular copper deficiency promotes the amyloidogenic processing of APP leading to increased A $\beta$ levels (Cater et al., 2008; Hung et al., 2009), whereas an elevation of intracellular copper levels promotes the non-amyloidogenic pathway and attenuates $A \beta$ generation in cells (Borchardt et al., 1999; White et al., 2006; Donnelly et al., 2008) as well as in transgenic mice (Cherny et al., 2001; Bayer et al., 2003; Phinney et al., 2003; Adlard et al., 2008). However, the molecular mechanisms leading to elevated $A \beta$ production in the presence of decreased cellular copper levels are currently elusive.

It has been suggested that copper induces conformational changes in APP that influence the monomer/dimer equilibrium and thus affects the proteolytic processing of APP (Kong et al., 2008; Baumkötter et al., 2014). In line, it has been shown that enhanced APP dimerization leads to reduced $A \beta$ generation (Kienlen-Campard et al., 2008; Eggert et al., 2009). On the other hand, it has been reported that attenuated APP dimerization correlates with reduced A $\beta$ levels (Munter et al., 2007; Kaden et al., 2008; Richter et al., 2010). Further studies will be required to solve this discrepancy.

An alternative mechanism underlying elevated $A \beta$ production in the presence of decreased cellular copper levels might concern the influence of copper on APP trafficking (Hung et al., 2009; Acevedo et al., 2011), either by altered conformational changes (Spoerri et al., 2012) or more indirectly by regulation of APP phosphorylation (Acevedo et al., 2014). Additionally, copper modifies $A \beta$ and accelerates its aggregation. The copperinduced $\mathrm{A} \beta$ oligomerization was found to contain a membranepenetrating structure (Curtain et al., 2001; Smith et al., 2006). As for other $A \beta$ aggregates, the copper-bound $A \beta$ oligomers complex have been shown to exhibit cytotoxic properties and vice versa general $\mathrm{A} \beta$ toxicity in tissue culture is partially dependent on copper (You et al., 2012).

Since more than a decade it is known, that copper may play also a detrimental role in $\mathrm{AD}$ due to its interaction with $\mathrm{A} \beta$-peptides leading to amyloid fibrilization, its influence on Tau and GSK3 $\beta$ and induction of oxidative stress (Kenche and Barnham, 2011). Based on these observations Bush and Tanzi (2008) have proposed the "Metal Hypothesis of AD". Therefore potential therapeutic strategies have been developed either targeting $A \beta$ copper interactions by selectively occupying the metal binding site on $\mathrm{A} \beta$ or through development of peptides effectively competing with $A \beta$-peptides for the metal ions. Such an approach has been developed e.g. for Wilson's disease (WD) to target a metal overload using metal chelators. Such chelators as desferrioxime, penicillamine and trientine have very high metal binding affinities and are hydrophilic. Therefore such chelators are inappropriate to tackle a brain disease like $\mathrm{AD}$ since they will not be able to cross the blood brain barrier (BBB). In contrast to these hydrophilic compounds metal protein attenuating compounds have been developed like clioquinol (CQ, 5-chloro-7-iodo-8hydroxyquinoline), which are indeed capable to cross the BBB. Although some approaches have been promising in early clinical trials none of these compounds have clinically proven to be effective in AD (Adlard et al., 2008; Lannfelt et al., 2008). One potential drawback might be the unwanted side effects on APP copper interactions and its subsequent physiological consequences.

\section{COPPER AND ZINC IN THE INTERPLAY WITH APP AT THE SYNAPSE}

Based on the observation that zinc and copper bind APP, APLP1 and APLP2 with high affinities and the high abundance 
of these metals in the synaptic cleft during neurotransmission, the impact of copper and zinc on the trans-cellular dimerization properties of APP during cell adhesion and synaptogenesis went into focus of current research.

\section{Influence of Copper on Brain Function}

The transition state metals copper and zinc, as well as iron, are essential for the catalytic activity of a variety of enzymes, including amongst others the cuproenzymes cytochrome $c$ oxidase, superoxide dismutase (SOD), ceruloplasmin, tyrosinase and dopamine $\beta$ hydroxylase (Turski and Thiele, 2009). However, copper is also toxic to cells and thus, its distribution in the cell has to be tightly regulated. In neurons, the copper transporter 1 (CTR1) mediates copper import (Lutsenko et al., 2010). Interestingly, only reduced copper (I) is transported by CTR1 (Macreadie, 2008). Thus, extracellular copper (II) has to be reduced to copper (I) by membrane bound metalloreductases prior to uptake into the cell by CTR1. The assumed mammalian metalloreductase remains to be identified (Lee J. et al., 2002). Potential candidates are the Steap proteins (Ohgami et al., 2006) as well as APP since it binds with high affinity to copper and is also able to reduce copper (Multhaup et al., 1996). However, elevated APP levels cause a decrease and APP depletion an increase of intracellular copper concentrations (White et al., 1999; Maynard et al., 2002, 2006; Phinney et al., 2003; Bellingham et al., 2004; Treiber et al., 2004), arguing against a function of APP in copper influx.

Copper imported via CTR1 is delivered by specific copper chaperones directly to different cuproenzymes. For example, the copper chaperone CCS mediates transfer of copper from CTR1 to the SOD (McCord and Fridovich, 1969; Culotta et al., 1997). Delivery of copper to cuproenzymes in the secretory pathway is mediated by the copper chaperone ATOX1, which transfers copper (I) from CTR1 to the intracellular copper transporters ATP7A and ATP7B, located in different intracellular compartments (Kim et al., 2008). Besides these principal metallochaperone mediated copper transport pathways, cytoplasmic copper also binds to glutathione immediately after entry into the cell and is subsequently transferred to metallothionein (Hung et al., 2010). Due to the described mechanisms, the intracellular concentration of free copper is maintained at exceedingly low levels (Rae et al., 1999).

Copper is found all over the brain and is most abundant in the basal ganglia (Madsen and Gitlin, 2007). The data on chelatable copper concentrations in extracellular fluids and intracellular compartments is a matter of debate. In some particular neurons copper is released at the synapse (Hartter and Barnea, 1988; Brown et al., 1997), estimated to reach upon depolarization and activation of N-methyl-D-aspartate (NMDA) receptors (Rajan et al., 1976; Hartter and Barnea, 1988; Kardos et al., 1989; Peters et al., 2011; Tamano and Takeda, 2011) micromolar concentrations (Kardos et al., 1989) to approx. $15 \mu \mathrm{M}$ (Hopt et al., 2003). Moreover, transient copper concentrations above $100 \mu \mathrm{M}$ at the synaptic cleft have been reported (Kardos et al., 1989; Gaier et al., 2013). Consistently, the synaptic cleft is the only reported microenvironment within the brain where chelatable copper might be easily excessible (Roberts et al., 2012). Interestingly, the activation of NMDA receptors leads to relocalization of ATP7A from the trans golgi-network (TGN) to neuronal processes and thus in turn contributes to increased copper concentrations at the synapse (Schlief et al., 2005).

Loss-of-function mutations in copper transporters, such as ATP7A and ATP7B, lead to hereditary diseases, Menkes disease (MD), or WD. Loss of ATP7A function causes growth failure, brittle hair, hypopigmentation, arterial tortuosity and neuronal loss most prominent in the hippocampus and cerebellum (Okeda et al., 1991; Chelly et al., 1993; Mercer et al., 1993; Vulpe et al., 1993). The phenotypes are mostly due to consequences of specific cuproenzymes dysfunction resulting from reduced cellular copper levels (D’Ambrosi and Rossi, 2015). Loss of ATP7B, which is primarily expressed in the liver, leads to copper overload in the liver and later in the brain, possibly due to impaired copper transport at the BBB (Huster and Lutsenko, 2007; Kaler, 2011). Although copper levels are mainly increased in cerebrospinal fluid and in the basal ganglia (Südmeyer et al., 2006), WD patients show widespread neuronal cell loss and white matter abnormalities, causing symptoms that include parkinsonism, seizures and mental disorders (Gitlin, 2003).

The molecular mechanisms underlying copper induced neurodegeneration are only partially understood. Mechanism(s) discussed involve S-nitrosylation, oxidation and allosteric modulation, increased anchorage of the neurotransmitter receptors to the membrane, and modulation of neurotransmitter receptor function (Weiser and Wienrich, 1996; Kim and Macdonald, 2003; Schlief and Gitlin, 2006; El Meskini et al., 2007; Huidobro-Toro et al., 2008; Peters et al., 2011; Gaier et al., 2013).

\section{Influence of Zinc on Brain Function}

In contrast to copper ions there is a substantial amount of zinc loosely bound to biomolecules, designated as reactive or chelatable zinc, which is implicated in neuronal signaling. Reactive zinc is largely distributed within presynaptic vesicles in some axon terminals throughout the telencephalon and co-localizes with a subset of glutamatergic neurons (Frederickson et al., 2000). Cytosolic reactive zinc levels are in the picomolar range and are estimated to rise to micromolar levels in the synaptic cleft and in intracellular compartments, such as mitochondria, secretory vesicles and lysosomes (Sensi et al., 2009). While it is evident that zinc is released during synaptic activity, there is little consensus on the amount or duration of its existence in the synaptic cleft (Watt et al., 2010). Zinc homeostasis is mainly maintained by regulated activities of "zinc importing" ZnT transporters (SLC30 family), "zinc exporting" ZIP transporters (SLC39 family), and zinc buffering proteins, including metallothioneins (Sensi et al., 2011). At the synapse, vesicular released zinc interacts with various neuronal ion channels (NMDA, ( $\alpha$-amino-3-hydroxy-5-methyl4-isoxazolepropionic acid, AMPA), $\mathrm{GABA}_{\mathrm{A}}$ ( $\gamma$-aminobutyric acid type A) receptors), Glycine and other surface receptors, such as TrkB. Furthermore, zinc can bind to and regulate ProSAPs/Shanks scaffolding proteins of the postsynaptic 
density (PSD), involved in synaptic signaling. Indeed, in some cerebral areas nearly $50 \%$ of the glutamatergic synapses are actually "glu-zinc-ergic" (Watt et al., 2010). Therefore, zinc is considered as an important synaptic modulator, affecting neurotransmission at inhibitory as well as excitatory synapses.

\section{Influence of Copper/Zinc on APP Synaptic Function}

Synaptic function of APP is discussed in detail in other chapters of this special issue. Briefly, loss of APP function leads to a reduced number of dendritic spines (Watt et al., 2010; Tyan et al., 2012) and to impairments in the structural plasticity (Zou et al., 2016). A possible mechanism infers an important trans-synaptic adhesion molecules like function for membrane anchored APP (Siddiqui and Craig, 2011) and major neurotrophic roles of the secreted $\mathrm{SAPP} \alpha$ ectodomain (Soba et al., 2005; Bell et al., 2008; Jimenez et al., 2011; Aydin et al., 2012; Caldwell et al., 2013; Baumkötter et al., 2014). Loss of APLP2 (von Koch et al., 1997) had no consequences on brain function (Weyer et al., 2011, 2014; Midthune et al., 2012), whereas APP/APLP2 and APLP1/APLP2 double KO mice exhibit severe deficits in formation of the neuromuscular junction and die early after birth. This suggests that APP/APLPs share some overlapping functions, but also have distinct synaptic functions that are not compensated by the other family members.

As pointed out before, copper binds APP at different sites within the E1 and E2 domain, causing structural changes and altered dimerization properties and heparin binding characteristics (Baumkötter et al., 2012). Copper binding to the GFLD coincides with structural rearrangements in the heparinbinding loop region (Baumkötter et al., 2014), possibly also representing an APP dimerization interface (Kaden et al., 2008). In line, copper-induced trans-directed in vitro interaction of APP, and mutations, abolishing copper-binding to the GFLD, reduce APP synaptogenic activity in a cellular assay system (Baumkötter et al., 2014). Therefore, it appears reasonable that copper might also modulate the neurotrophic function of secreted APP forms. Thus, copper modulation in the synaptic cleft upon synaptic activity might contribute to APP transsynaptic signaling in context of synaptic maturation (Figure 5). Actually, a decrease of D-serine in brains of APP knockout mice was reported to contribute to synaptic deficits in aged mice (Zou et al., 2016). Most likely the decrease in D-serine is explained by a loss of function of APP in calciumdependent release of $\mathrm{D}$-serine from astrocytes (Martineau et al., 2014). Thus, as both D-serine and zinc can bind and modulate NMDA receptor function in antagonistic ways, it is tempting to speculate that APP might sense changes in zinc concentrations that in turn could affect D-serine secretion in the synaptic cleft, antagonizing the antidepressant-like effects of zinc and thereby contributes to homeostasis of synaptic activity. A validation of this tempting hypothesis is however hampered by the technical limitation for the quantification of reactive copper in the synaptic cleft. Knock-in approaches testing different APP mutants might be a way to disentangle

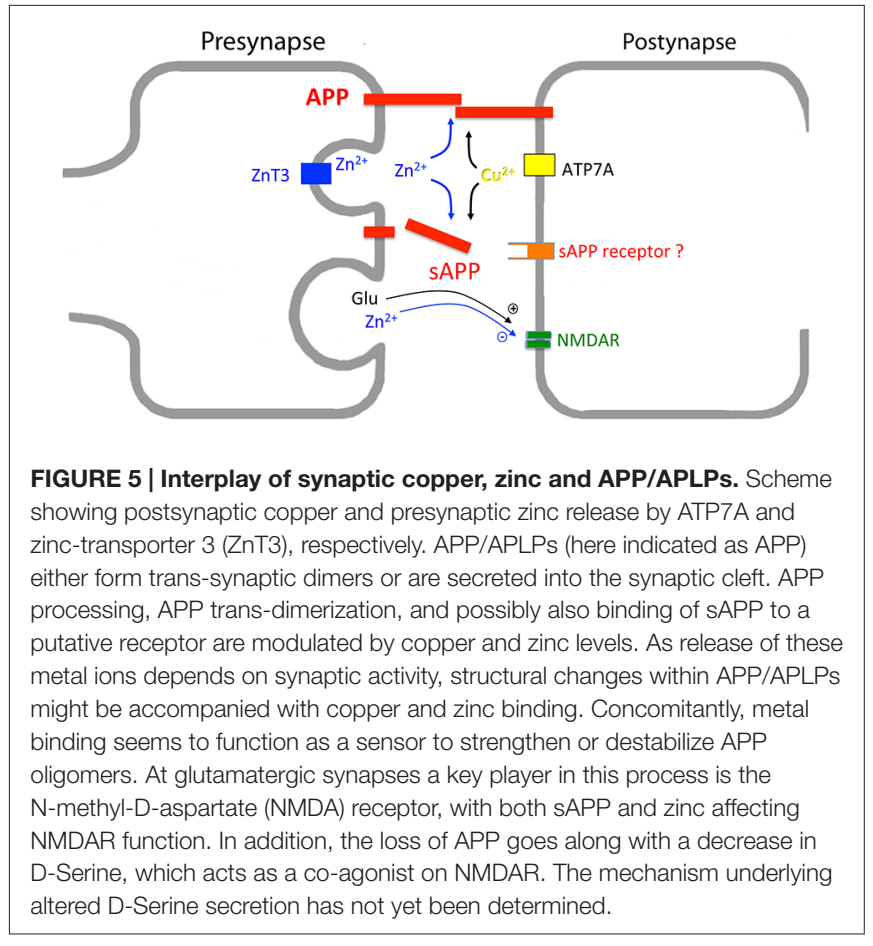

the functional relation between copper and APP at the synapse.

Different reports suggest binding of APP, APLP1 and to a minor extent also APLP2 to zinc with affinities in the low micromolar range (Bush et al., 1993; Mayer et al., 2014, 2016) and it was shown by FRET analysis of heterologous expressed APP/APLPs that addition of zinc can induce clustering of APP, APLP1 (EC50: $10 \mu \mathrm{M})$, and APLP2 (EC50: $300 \mu \mathrm{M})$ as well as of all types of heterotypic APP/APLPs combinations (Mayer et al., 2016). Interestingly, combinations of APLP1 with APLP2 also exhibited an EC50 at about $50 \mu \mathrm{M}$. As reactive zinc concentrations can reach high micromolar and possibly also millimolar concentrations in the synaptic cleft, all types of oligomers (including homo- and heterotypic APLP2 containing oligomers) are likely formed also under in vivo conditions at the synapse. Consistently, addition of $50 \mu \mathrm{M}$ zinc to cells expressing APLP1 caused a lateral concentration at cell-cell contact sites (Mayer et al., 2016), as formerly described by Soba et al. (2005) in presence of copper (Baumkötter et al., 2014). Notably, alanine mutations of one of four histidines involved in zinc binding at the M3 site $(\mathrm{H} 430 / \mathrm{H} 433 / \mathrm{H} 450 / \mathrm{H} 452)$ did not abolish zinc-induced oligomerization and only lowered the affinity about two fold. This suggests that APP and APLP2 transdirected dimerization might also be affected by zinc in a similar way, possibly in interplay with heparin binding and APP/APLPs dimerization/oligomerization (Bush et al., 1994a).

Despite some major gaps in our understanding of APP/APLPs synaptic function, the current data as presented in this review article strongly suggest that activity-dependent changes in zinc and copper concentrations in the synaptic cleft can be sensed by the APP/APLP family. In turn, they seem to modulate neurotransmission by different pathways including neurotrophic 
activity of $\operatorname{sAPP} \alpha$ or trans-cellular dimerization/signaling. However, one major gap in our current understanding, especially in respect to the function of copper, is the limitation of available sensitive sensors, allowing determination of local transient changes in copper concentration. In this regard, live-cell optical imaging with fluorescent sensors offers a potentially powerful approach for interrogating aspects of labile copper accumulation, speciation, trafficking, and redox function in living systems at the molecular level. Such reagents have greatly facilitated the study of calcium and zinc in cell biology, but analogs tools for cellular copper remain underdeveloped (Zeng et al., 2006; Dean et al., 2012). Therefore, the most promising way might actually be, to use mutant APP impaired in copper and/or zinc binding in different cellular assays, allowing to estimate the

\section{REFERENCES}

Acevedo, K. M., Hung, Y. H., Dalziel, A. H., Li, Q. X., Laughton, K., Wikhe, K., et al. (2011). Copper promotes the trafficking of the amyloid precursor protein. J. Biol. Chem. 286, 8252-8262. doi: 10.1074/jbc.M110. 128512

Acevedo, K. M., Opazo, C. M., Norrish, D., Challis, L. M., Li, Q. X., White, A. R., et al. (2014). Phosphorylation of amyloid precursor protein at threonine 668 is essential for its copper-responsive trafficking in SH-SY5Y neuroblastoma cells. J. Biol. Chem. 289, 11007-11019. doi: 10.1074/jbc.m113.538710

Adlard, P. A., and Bush, A. I. (2006). Metals and Alzheimer's disease. J. Alzheimers Dis. 10, 145-163.

Adlard, P. A., Cherny, R. A., Finkelstein, D. I., Gautier, E., Robb, E., Cortes, M., et al. (2008). Rapid restoration of cognition in Alzheimer's transgenic mice with 8-hydroxy quinoline analogs is associated with decreased interstitial $A \beta$. Neuron 59, 43-55. doi: 10.1016/j.neuron.2008.06.018

Atwood, C. S., Moir, R. D., Huang, X., Scarpa, R. C., Bacarra, N. M., Romano, D. M., et al. (1998). Dramatic aggregation of Alzheimer abeta by $\mathrm{Cu}(\mathrm{II})$ is induced by conditions representing physiological acidosis. J. Biol. Chem. 273, 12817-12826. doi: 10.1074/jbc.273.21.12817

Atwood, C. S., Perry, G., Zeng, H., Kato, Y., Jones, W. D., Ling, K. Q., et al. (2004). Copper mediates dityrosine cross-linking of Alzheimer's amyloid- $\beta$. Biochemistry 43, 560-568. doi: 10.1021/bi0358824

Aydin, D., Weyer, S. W., and Muller, U. C. (2012). Functions of the APP gene family in the nervous system: insights from mouse models. Exp. Brain Res. 217, 423-434. doi: 10.1007/s00221-011-2861-2

Ayton, S., Lei, P., and Bush, A. I. (2013). Metallostasis in Alzheimer's disease. Free Radic. Biol. Med. 62, 76-89. doi: 10.1016/j.freeradbiomed.2012. 10.558

Barnham, K. J., McKinstry, W. J., Multhaup, G., Galatis, D., Morton, C. J., Curtain, C. C., et al. (2003). Structure of the Alzheimer's disease amyloid precursor protein copper binding domain. A regulator of neuronal copper homeostasis. J. Biol. Chem. 278, 17401-17407. doi: 10.1074/jbc.m3006 29200

Baumkötter, F., Schmidt, N., Vargas, C., Schilling, S., Weber, R., Wagner, K., et al. (2014). Amyloid precursor protein dimerization and synaptogenic function depend on copper binding to the growth factor-like domain. J. Neurosci. 34, 11159-11172. doi: 10.1523/JNEUROSCI.0180-14.2014

Baumkötter, F., Wagner, K., Eggert, S., Wild, K., and Kins, S. (2012). Structural aspects and physiological consequences of APP/APLP transdimerization. Exp. Brain Res. 217, 389-395. doi: 10.1007/s00221-0112878-6

Bayer, T. A., Schäfer, S., Simons, A., Kemmling, A., Kamer, T., Tepest, R., et al. (2003). Dietary Cu stabilizes brain superoxide dismutase 1 activity and reduces amyloid A $\beta$ production in APP23 transgenic mice. Proc. Natl. Acad. Sci. U S A 100, 14187-14192. doi: 10.1073/pnas.2332818100

Bell, K. F., Zheng, L., Fahrenholz, F., and Cuello, A. C. (2008). ADAM-10 over-expression increases cortical synaptogenesis. Neurobiol. Aging 29, 554-565. doi: 10.1016/j.neurobiolaging.2006.11.004 pathophysiological impact of copper and zinc on APP function and its role in $\mathrm{AD}$.

\section{AUTHOR CONTRIBUTIONS}

KW, AA, CUP and SK wrote this review article.

\section{ACKNOWLEDGMENTS}

Research in our laboratories was funded by the Deutsche Forschungsgemeinschaft (FOR1332, to CUP, KW and SK) and the Stiftung Rheinland-Pfalz für Innovation (to CUP and SK). KW acknowledges generous support by Irmgard Sinning at the Heidelberg University Biochemistry Center (BZH).

Bellingham, S. A., Ciccotosto, G. D., Needham, B. E., Fodero, L. R., White, A. R. Masters, C. L., et al. (2004). Gene knockout of amyloid precursor protein and amyloid precursor-like protein-2 increases cellular copper levels in primary mouse cortical neurons and embryonic fibroblasts. J. Neurochem. 91, 423-428. doi: 10.1111/j.1471-4159.2004.02731.x

Bien, J., Jefferson, T., Causevic, M., Jumpertz, T., Munter, L., Multhaup, G., et al. (2012). The metalloprotease meprin $\beta$ generates amino terminal-truncated amyloid $\beta$ peptide species. J. Biol. Chem. 287, 33304-33313. doi: 10.1074/jbc. M112.395608

Borchardt, T., Camakaris, J., Cappai, R., Masters, C. L., Beyreuther, K., and Multhaup, G. (1999). Copper inhibits $\beta$-amyloid production and stimulates the non-amyloidogenic pathway of amyloid-precursor-protein secretion. Biochem. J. 344, 461-467. doi: 10.1042/0264-6021:3440461

Brown, D. R., Qin, K., Herms, J. W., Madlung, A., Manson, J., Strome, R., et al. (1997). The cellular prion protein binds copper in vivo. Nature 390, 684-687.

Brunholz, S., Sisodia, S., Lorenzo, A., Deyts, C., Kins, S., and Morfini, G. (2012). Axonal transport of APP and the spatial regulation of APP cleavage and function in neuronal cells. Exp. Brain Res. 217, 353-364. doi: 10.1007/s00221011-2870-1

Bush, A. I., Pettingell, W. H. Jr., de Paradis, M., Tanzi, R. E., and Wasco, W. (1994a). The amyloid beta-protein precursor and its mammalian homologues. Evidence for a zinc-modulated heparin-binding superfamily. J. Biol. Chem. 269, 26618-26621.

Bush, A. I., Pettingell, W. H. Jr., Paradis, M. D., and Tanzi, R. E. (1994b). Modulation of A beta adhesiveness and secretase site cleavage by zinc. J. Biol. Chem. 269, 12152-12158.

Bush, A. I., Pettingell, W. H., Multhaup, G., d Paradis, M., Vonsattel, J. P., Gusella, J. F., et al. (1994c). Rapid induction of Alzheimer A beta amyloid formation by zinc. Science 265, 1464-1467. doi: 10.1126/science. 8073293

Bush, A. I., Multhaup, G., Moir, R. D., Williamson, T. G., Small, D. H., Rumble, B., et al. (1993). A novel zinc(II) binding site modulates the function of the beta A4 amyloid protein precursor of Alzheimer's disease. J. Biol. Chem. 268, 16109-16112.

Bush, A. I., and Tanzi, R. E. (2008). Therapeutics for Alzheimer's disease based on the metal hypothesis. Neurotherapeutics 5, 421-432. doi: 10.1016/j.nurt.2008. 05.001

Caldwell, J. H., Klevanski, M., Saar, M., and Müller, U. C. (2013). Roles of the amyloid precursor protein family in the peripheral nervous system. Mech. Dev. 130, 433-446. doi: 10.1016/j.mod.2012.11.001

Casey, J. R., Grinstein, S., and Orlowski, J. (2010). Sensors and regulators of intracellular pH. Nat. Rev. Mol. Cell. Biol. 11, 50-61. doi: 10.1038/ nrm 2820

Cater, M. A., McInnes, K. T., Li, Q. X., Volitakis, I., La Fontaine, S., Mercer, J. F., et al. (2008). Intracellular copper deficiency increases amyloid- $\beta$ secretion by diverse mechanisms. Biochem. J. 412, 141-152. doi: 10.1042/bj20080103

Chelly, J., Tümer, Z., Tønnesen, T., Petterson, A., Ishikawa-Brush, Y., Tommerup, N., et al. (1993). Isolation of a candidate gene for Menkes disease 
that encodes a potential heavy metal binding protein. Nat. Genet. 3, 14-19. doi: 10.1038/ng0193-14

Cherny, R. A., Atwood, C. S., Xilinas, M. E., Gray, D. N., Jones, W. D., McLean, C. A., et al. (2001). Treatment with a copper-zinc chelator markedly and rapidly inhibits $\beta$-amyloid accumulation in Alzheimer's disease transgenic mice. Neuron 30, 665-676. doi: 10.1016/s0896-6273(01)00317-8

Coburger, I., Hoefgen, S., and Than, M. E. (2014). The structural biology of the amyloid precursor protein APP - a complex puzzle reveals its multi-domain architecture. Biol. Chem. 395, 485-498. doi: 10.1515/hsz-2013-0280

Culotta, V. C., Klomp, L. W., Strain, J., Casareno, R. L., Krems, B., and Gitlin, J. D. (1997). The copper chaperone for superoxide dismutase. J. Biol. Chem. 272, 23469-23472. doi: 10.1074/jbc.272.38.23469

Curtain, C. C., Ali, F., Volitakis, I., Cherny, R. A., Norton, R. S., Beyreuther, K., et al. (2001). Alzheimer's disease amyloid- $\beta$ binds copper and zinc to generate an allosterically ordered membrane-penetrating structure containing superoxide dismutase-like subunits. J. Biol. Chem. 276, 20466-20473. doi: 10.1074/jbc.m100175200

Dahms, S. O., Könnig, I., Roeser, D., Gührs, K. H., Mayer, M. C., Kaden, D., et al. (2012). Metal binding dictates conformation and function of the amyloid precursor protein (APP) E2 domain. J. Mol. Biol. 416, 438-452. doi: 10.1016/j. jmb.2011.12.057

Dahms, S. O., Mayer, M. C., Roeser, D., Multhaup, G., and Than, M. E. (2015). Interaction of the amyloid precursor protein-like protein 1 (APLP1) E2 domain with heparan sulfate involves two distinct binding modes. Acta Crystallogr. D Biol. Crystallogr. 71, 494-504. doi: 10.1107/S1399004714027114

Damante, C. A., Osz, K., Nagy, Z., Pappalardo, G., Grasso, G., Impellizzeri, G., et al. (2009). Metal loading capacity of A $\beta \mathrm{N}$-terminus: a combined potentiometric and spectroscopic study of zinc(II) complexes with $\mathrm{A} \beta(1-16)$, its short or mutated peptide fragments and its polyethylene glycol-ylated analogue. Inorg. Chem. 48, 10405-10415. doi: 10.1021/ic9012334

D’Ambrosi, N., and Rossi, L. (2015). Copper at synapse: release, binding and modulation of neurotransmission. Neurochem. Int. 90, 36-45. doi: 10.1016/j. neuint.2015.07.006

Dean, K. M., Qin, Y., and Palmer, A. E. (2012). Visualizing metal ions in cells: an overview of analytical techniques, approaches and probes. Biochim. Biophys. Acta 1823, 1406-1415. doi: 10.1016/j.bbamcr.2012.04.001

Deibel, M. A., Ehmann, W. D., and Markesbery, W. R. (1996). Copper, iron and zinc imbalances in severely degenerated brain regions in Alzheimer's disease: possible relation to oxidative stress. J. Neurol. Sci. 143, 137-142. doi: 10.1016/s0022-510x(96)00203-1

Dienemann, C., Coburger, I., Mehmedbasic, A., Andersen, O. M., and Than, M. E. (2015). Mutants of metal binding site M1 in APP E2 show metal specific differences in binding of heparin but not of sorLA. Biochemistry 54, 2490-2499. doi: 10.1021/acs.biochem.5b00111

Dong, J., Atwood, C. S., Anderson, V. E., Siedlak, S. L., Smith, M. A., Perry, G., et al. (2003). Metal binding and oxidation of amyloid- $\beta$ within isolated senile plaque cores: Raman microscopic evidence. Biochemistry 42, 2768-2773. doi: 10. 1021/bi0272151

Donnelly, P. S., Caragounis, A., Du, T., Laughton, K. M., Volitakis, I., Cherny, R. A., et al. (2008). Selective intracellular release of copper and zinc ions from bis(thiosemicarbazonato) complexes reduces levels of Alzheimer disease amyloid- $\beta$ peptide. J. Biol. Chem. 283, 4568-4577. doi: 10.1074/jbc. m705957200

Eggert, S., Midthune, B., Cottrell, B., and Koo, E. H. (2009). Induced dimerization of the amyloid precursor protein leads to decreased amyloid- $\beta$ protein production. J. Biol. Chem. 284, 28943-28952. doi: 10.1074/jbc.m109.038646

El Meskini, R., Crabtree, K. L., Cline, L. B., Mains, R. E., Eipper, B. A., and Ronnett, G. V. (2007). ATP7A (Menkes protein) functions in axonal targeting and synaptogenesis. Mol. Cell. Neurosci. 34, 409-421. doi: 10.1016/j.mcn.2006. 11.018

Faller, P., Hureau, C., and Berthoumieu, O. (2013). Role of metal ions in the self-assembly of the Alzheimer's amyloid- $\beta$ peptide. Inorg. Chem. 52, 12193-12206. doi: 10.1021/ic4003059

Frederickson, C. J., Suh, S. W., Silva, D., and Thompson, R. B. (2000). Importance of zinc in the central nervous system: the zinc-containing neuron. J. Nutr. 130, (5S Suppl), 1471S-1483S.

Friedlich, A. L., Lee, J. Y., van Groen, T., Cherny, R. A., Volitakis, I., Cole, T. B., et al. (2004). Neuronal zinc exchange with the blood vessel wall promotes cerebral amyloid angiopathy in an animal model of Alzheimer's disease. J. Neurosci. 24, 3453-3459. doi: 10.1523/JNEUROSCI.0297-04.2004

Gaier, E. D., Eipper, B. A., and Mains, R. E. (2013). Copper signaling in the mammalian nervous system: synaptic effects. J. Neurosci. Res. 91, 2-19. doi: 10.1002/jnr.23143

Gitlin, J. D. (2003). Wilson disease. Gastroenterology 125, 1868-1877. doi: 10.1053/j.gastro.2003.05.010

Haass, C., Kaether, C., Thinakaran, G., and Sisodia, S. (2012). Trafficking and proteolytic processing of APP. Cold Spring Harb. Perspect. Med. 2:a006270. doi: $10.1101 /$ cshperspect.a006270

Hartter, D. E., and Barnea, A. (1988). Evidence for release of copper in the brain: depolarization-induced release of newly taken-up 67copper. Synapse 2 , 412-415. doi: 10.1002/syn.890020408

Hesse, L., Beher, D., Masters, C. L., and Multhaup, G. (1994). The BA4 amyloid precursor protein binding to copper. FEBS Lett. 349, 109-116. doi: 10.1016/0014-5793(94)00658-x

Hoefgen, S., Dahms, S. O., Oertwig, K., and Than, M. E. (2015). The amyloid precursor protein shows a $\mathrm{pH}$-dependent conformational switch in its E1 domain. J. Mol. Biol. 427, 433-442. doi: 10.1016/j.jmb.2014.12.005

Hopt, A., Korte, S., Fink, H., Panne, U., Niessner, R., Jahn, R., et al. (2003). Methods for studying synaptosomal copper release. J. Neurosci. Methods 128 159-172. doi: 10.1016/s0165-0270(03)00173-0

Huang, X., Atwood, C. S., Hartshorn, M. A., Multhaup, G., Goldstein, L. E., Scarpa, R. C., et al. (1999). The A $\beta$ peptide of Alzheimer's disease directly produces hydrogen peroxide through metal ion reduction. Biochemistry 38, 7609-7616. doi: 10.1021/bi990438f

Huang, L., and Tepaamorndech, S. (2013). The SLC30 family of zinc transporters-a review of current understanding of their biological and pathophysiological roles. Mol. Aspects Med. 34, 548-560. doi: 10.1016/j.mam. 2012.05.008

Huidobro-Toro, J. P., Lorca, R. A., and Coddou, C. (2008). Trace metals in the brain: allosteric modulators of ligand-gated receptor channels, the case of ATP-gated P2X receptors. Eur. Biophys. J. 37, 301-314. doi: 10.1007/s00249007-0230-7

Hung, Y. H., Bush, A. I., and Cherny, R. A. (2010). Copper in the brain and Alzheimer's disease. J. Biol. Inorg. Chem. 15, 61-76. doi: 10.1007/s00775-0090600-y

Hung, Y. H., Robb, E. L., Volitakis, I., Ho, M., Evin, G., Li, Q. X., et al. (2009). Paradoxical condensation of copper with elevated $\beta$-amyloid in lipid rafts under cellular copper deficiency conditions: implications for Alzheimer disease. J. Biol. Chem. 284, 21899-21907. doi: 10.1074/jbc.m109. 019521

Huster, D., and Lutsenko, S. (2007). Wilson disease: not just a copper disorder. Analysis of a Wilson disease model demonstrates the link between copper and lipid metabolism. Mol. Biosyst. 3, 816-824. doi: 10.1039/b711118p

Isbert, S., Wagner, K., Eggert, S., Schweitzer, A., Multhaup, G., Weggen, S., et al. (2012). APP dimer formation is initiated in the endoplasmic reticulum and differs between APP isoforms. Cell. Mol. Life Sci. 69, 1353-1375. doi: 10 1007/s00018-011-0882-4

Jimenez, S., Torres, M., Vizuete, M., Sanchez-Varo, R., Sanchez-Mejias, E., Trujillo-Estrada, L., et al. (2011). Age-dependent accumulation of soluble amyloid $\beta(\mathrm{A} \beta)$ oligomers reverses the neuroprotective effect of soluble amyloid precursor protein- $\alpha(\operatorname{sAPP}(\alpha))$ by modulating phosphatidylinositol 3-kinase (PI3K)/Akt-GSK-3 $\beta$ pathway in Alzheimer mouse model. J. Biol. Chem. 286, 18414-18425. doi: 10.1074/jbc.m110.209718

Kaden, D., Munter, L. M., Joshi, M., Treiber, C., Weise, C., Bethge, T., et al. (2008). Homophilic interactions of the amyloid precursor protein (APP) ectodomain are regulated by the loop region and affect $\beta$-secretase cleavage of APP. J. Biol. Chem. 283, 7271-7279. doi: 10.1074/jbc.m708046200

Kaler, S. G. (2011). ATP7A-related copper transport diseases-emerging concepts and future trends. Nat. Rev. Neurol. 7, 15-29. doi: 10.1038/nrneurol.2010.180

Kardos, J., Kovács, I., Hajós, F., Kálmán, M., and Simonyi, M. (1989). Nerve endings from rat brain tissue release copper upon depolarization. A possible role in regulating neuronal excitability. Neurosci. Lett. 103, 139-144. doi: 10. 1016/0304-3940(89)90565-x

Kenche, V. B., and Barnham, K. J. (2011). Alzheimer's disease and metals: therapeutic opportunities. Br. J. Pharmacol. 163, 211-219. doi: 10.1111/j.14765381.2011.01221.x 
Kienlen-Campard, P., Tasiaux, B., Van Hees, J., Li, M., Huysseune, S., Sato, T., et al. (2008). Amyloidogenic processing but not amyloid precursor protein (APP) intracellular C-terminal domain production requires a precisely oriented APP dimer assembled by transmembrane GXXXG motifs. J. Biol. Chem. 283, 7733-7744. doi: 10.1074/jbc.m707142200

Kim, H., and Macdonald, R. L. (2003). An N-terminal histidine is the primary determinant of $\alpha$ subunit-dependent $\mathrm{Cu}^{2+}$ sensitivity of $\alpha \beta 3 \gamma 2 \mathrm{~L} \mathrm{GABA}_{\mathrm{A}}$ receptors. Mol. Pharmacol. 64, 1145-1152. doi: 10.1124/mol.64.5.1145

Kim, B. E., Nevitt, T., and Thiele, D. J. (2008). Mechanisms for copper acquisition, distribution and regulation. Nat. Chem. Biol. 4, 176-185. doi: $10.1038 /$ nchembio.72

von Koch, C. S., Zheng, H., Chen, H., Trumbauer, M., Thinakaran, G., van der Ploeg, L. H., et al. (1997). Generation of APLP2 KO mice and early postnatal lethality in APLP2/APP double KO mice. Neurobiol. Aging 18, 661-669. doi: 10.1016/s0197-4580(97)00151-6

Koh, J. Y., Suh, S. W., Gwag, B. J., He, Y. Y., Hsu, C. Y., and Choi, D. W. (1996). The role of zinc in selective neuronal death after transient global cerebral ischemia. Science 272, 1013-1016. doi: 10.1126/science.272.5264.1013

Kong, G. K., Adams, J. J., Harris, H. H., Boas, J. F., Curtain, C. C., Galatis, D., et al. (2007). Structural studies of the Alzheimer's amyloid precursor protein copperbinding domain reveal how it binds copper ions. J. Mol. Biol. 367, 148-161. doi: 10.1016/j.jmb.2006.12.041

Kong, G. K., Miles, L. A., Crespi, G. A., Morton, C. J., Ng, H. L., Barnham, K. J., et al. (2008). Copper binding to the Alzheimer's disease amyloid precursor protein. Eur. Biophys. J. 37, 269-279. doi: 10.1007/s00249-007-0234-3

Lammich, S., Kojro, E., Postina, R., Gilbert, S., Pfeiffer, R., Jasionowski, M., et al. (1999). Constitutive and regulated $\alpha$-secretase cleavage of Alzheimer's amyloid precursor protein by a disintegrin metalloprotease. Proc. Natl. Acad. Sci. U S A 96, 3922-3927. doi: 10.1073/pnas.96.7.3922

Lannfelt, L., Blennow, K., Zetterberg, H., Batsman, S., Ames, D., Harrison, J., et al. (2008). Safety, efficacy and biomarker findings of PBT2 in targeting $\mathrm{A} \beta$ as a modifying therapy for Alzheimer's disease: a phase IIa, doubleblind, randomised, placebo-controlled trial. Lancet Neurol. 7, 779-786. doi: 10. 1016/S1474-4422(08)70167-4

Lee, J.-Y., Cole, T. B., Palmiter, R. D., Suh, S. W., and Koh, J. Y. (2002). Contribution by synaptic zinc to the gender-disparate plaque formation in human Swedish mutant APP transgenic mice. Proc. Natl. Acad. Sci. U S A 99, 7705-7710. doi: 10.1073/pnas.092034699

Lee, J., Peña, M. M., Nose, Y., and Thiele, D. J. (2002). Biochemical characterization of the human copper transporter Ctr1. J. Biol. Chem. 277, 4380-4387. doi: 10.1074/jbc.M104728200

Lee, S., Xue, Y., Hu, J., Wang, Y., Liu, X., Demeler, B., et al. (2011). The E2 domains of APP and APLP1 share a conserved mode of dimerization. Biochemistry 50, 5453-5464. doi: 10.1021/bi101846x

Leskovjan, A. C., Lanzirotti, A., and Miller, L. M. (2009). Amyloid plaques in PSAPP mice bind less metal than plaques in human Alzheimer's disease. Neuroimage 47, 1215-1220. doi: 10.1016/j.neuroimage.2009.05.063

Lovell, M. A., Robertson, J. D., Teesdale, W. J., Campbell, J. L., and Markesbery, W. R. (1998). Copper, iron and zinc in Alzheimer's disease senile plaques. J. Neurol. Sci. 158, 47-52. doi: 10.1016/s0022-510x(98)00092-6

Lutsenko, S., Bhattacharjee, A., and Hubbard, A. L. (2010). Copper handling machinery of the brain. Metallomics 2, 596-608. doi: 10.1039/c0mt00006j

Macreadie, I. G. (2008). Copper transport and Alzheimer's disease. Eur. Biophys. J. 37, 295-300. doi: 10.1007/s00249-007-0235-2

Madsen, E., and Gitlin, J. D. (2007). Copper deficiency. Curr. Opin. Gastroenterol. 23, 187-192. doi: 10.1097/MOG.0b013e32801421bb

Magaki, S., Raghavan, R., Mueller, C., Oberg, K. C., Vinters, H. V., and Kirsch, W. M. (2007). Iron, copper and iron regulatory protein 2 in Alzheimer's disease and related dementias. Neurosci. Lett. 418, 72-76. doi: 10.1016/j.neulet. 2007.02.077

Martineau, M., Parpura, V., and Mothet, J. P. (2014). Cell-type specific mechanisms of D-serine uptake and release in the brain. Front. Synaptic Neurosci. 6:12. doi: 10.3389/fnsyn.2014.00012

Masters, C. L., and Selkoe, D. J. (2012). Biochemistry of amyloid $\beta$-protein and amyloid deposits in Alzheimer disease. Cold Spring Harb. Perspect. Med. 2:a006262. doi: 10.1101/cshperspect.a006262

Mayer, M. C., Kaden, D., Schauenburg, L., Hancock, M. A., Voigt, P., Roeser, D., et al. (2014). Novel zinc-binding site in the E2 domain regulates amyloid precursor-like protein 1 (APLP1) oligomerization. J. Biol. Chem. 289, 19019-19030. doi: 10.1074/jbc.M114.570382

Mayer, M. C., Schauenburg, L., Thompson-Steckel, G., Dunsing, V., Kaden, D., Voigt, P., et al. (2016). Amyloid precursor-like protein 1 (APLP1) exhibits stronger zinc-dependent neuronal adhesion than amyloid precursor protein and APLP2. J. Neurochem. 137, 266-276. doi: 10.1111/jnc.13540

Maynard, C. J., Cappai, R., Volitakis, I., Cherny, R. A., Masters, C. L., Li, Q. X., et al. (2006). Gender and genetic background effects on brain metal levels in APP transgenic and normal mice: implications for Alzheimer $\beta$-amyloid pathology. J. Inorg. Biochem. 100, 952-962. doi: 10.1016/j.jinorgbio.2006.02.010

Maynard, C. J., Cappai, R., Volitakis, I., Cherny, R. A., White, A. R., Beyreuther, K., et al. (2002). Overexpression of Alzheimer's disease amyloid- $\beta$ opposes the age-dependent elevations of brain copper and iron. J. Biol. Chem. 277, 44670-44676. doi: 10.1074/jbc.m204379200

McCord, J. M., and Fridovich, I. (1969). The utility of superoxide dismutase in studying free radical reactions. I. Radicals generated by the interaction of sulfite, dimethyl sulfoxide, and oxygen. J. Biol. Chem. 244, 6056-6063.

Mercer, J. F., Livingston, J., Hall, B., Paynter, J. A., Begy, C., Chandrasekharappa, S., et al. (1993). Isolation of a partial candidate gene for Menkes disease by positional cloning. Nat. Genet. 3, 20-25. doi: 10. 1038/ng0193-20

Midthune, B., Tyan, S. H., Walsh, J. J., Sarsoza, F., Eggert, S., Hof, P. R., et al. (2012). Deletion of the amyloid precursor-like protein 2 (APLP2) does not affect hippocampal neuron morphology or function. Mol. Cell Neurosci. 49, 448-455. doi: 10.1016/j.mcn.2012.02.001

Miller, C. C., McLoughlin, D. M., Lau, K. F., Tennant, M. E., and Rogelj, B. (2006). The X11 proteins, $\mathrm{A} \beta$ production and Alzheimer's disease. Trends Neurosci. 29, 280-285. doi: 10.1016/j.tins.2006.03.001

Müller, U. C., and Zheng, H. (2012). Physiological functions of APP family proteins. Cold Spring Harb. Perspect. Med. 2:a006288. doi: 10.1101/cshperspect. a006288

Multhaup, G., Schlicksupp, A., Hesse, L., Beher, D., Ruppert, T., Masters, C. L., et al. (1996). The amyloid precursor protein of Alzheimer's disease in the reduction of copper(II) to copper(I). Science 271, 1406-1409. doi: 10 1126/science.271.5254.1406

Munter, L. M., Voigt, P., Harmeier, A., Kaden, D., Gottschalk, K. E., Weise, C., et al. (2007). GxxxG motifs within the amyloid precursor protein transmembrane sequence are critical for the etiology of $A \beta 42 . E M B O ~ J .26$, 1702-1712. doi: 10.1038/sj.emboj.7601616

Muresan, V., and Ladescu Muresan, Z. (2015). Amyloid- $\beta$ precursor protein: multiple fragments, numerous transport routes and mechanisms. Exp. Cell Res. 334, 45-53. doi: 10.1016/j.yexcr.2014.12.014

Ohgami, R. S., Campagna, D. R., McDonald, A., and Fleming, M. D. (2006). The steap proteins are metalloreductases. Blood 108, 1388-1394. doi: 10.1182/blood-2006-02-003681

Okeda, R., Gei, S., Chen, I., Okaniwa, M., Shinomiya, M., and Matsubara, O. (1991). Menkes' kinky hair disease: morphological and immunohistochemical comparison of two autopsied patients. Acta Neuropathol. 81, 450-457. doi: 10.1007/bf00293467

Palmiter, R. D., Cole, T. B., Quaife, C. J., and Findley, S. D. (1996). ZnT-3, a putative transporter of zinc into synaptic vesicles. Proc. Natl. Acad. Sci. U S A 93, 14934-14939. doi: 10.1073/pnas.93.25.14934

Peters, C., Muñoz, B., Sepúlveda, F. J., Urrutia, J., Quiroz, M., Luza, S., et al. (2011). Biphasic effects of copper on neurotransmission in rat hippocampal neurons. J. Neurochem. 119, 78-88. doi: 10.1111/j.1471-4159.2011.07417.x

Phinney, A. L., Drisaldi, B., Schmidt, S. D., Lugowski, S., Coronado, V., Liang, Y., et al. (2003). In vivo reduction of amyloid- $\beta$ by a mutant copper transporter. Proc. Natl. Acad. Sci. U S A 100, 14193-14198. doi: 10.1073/pnas.2332851100

Rae, T. D., Schmidt, P. J., Pufahl, R. A., Culotta, V. C., and O’Halloran, T. V. (1999). Undetectable intracellular free copper: the requirement of a copper chaperone for superoxide dismutase. Science 284, 805-808. doi: 10.1126/science.284.5415. 805

Rajan, K. S., Colburn, R. W., and Davis, J. M. (1976). Distribution of metal ions in the subcellular fractions of several rat brain areas. Life Sci. 18, 423-431. doi: 10 1016/0024-3205(76)90220-4

Religa, D., Strozyk, D., Cherny, R. A., Volitakis, I., Haroutunian, V., Winblad, B., et al. (2006). Elevated cortical zinc in Alzheimer disease. Neurology 67, 69-75. doi: 10.1212/01.wnl.0000223644.08653.b5 
Richter, L., Munter, L. M., Ness, J., Hildebrand, P. W., Dasari, M., Unterreitmeier, S., et al. (2010). Amyloid beta 42 peptide (A $\beta 42)$-lowering compounds directly bind to $\mathrm{A} \beta$ and interfere with amyloid precursor protein (APP) transmembrane dimerization. Proc. Natl. Acad. Sci. U S A 107, 14597-14602. doi: 10.1073/pnas.1003026107

Roberts, B. R., Ryan, T. M., Bush, A. I., Masters, C. L., and Duce, J. A. (2012). The role of metallobiology and amyloid- $\beta$ peptides in Alzheimer's disease. J. Neurochem. 120, 149-166. doi: 10.1111/j.1471-4159.2011.07500.x

Schaller, S., Mauskopf, J., Kriza, C., Wahlster, P., and Kolominsky-Rabas, P. L. (2015). The main cost drivers in dementia: a systematic review. Int. J. Geriatr. Psychiatry 30, 111-129. doi: 10.1002/gps.4198

Schlief, M. L., Craig, A. M., and Gitlin, J. D. (2005). NMDA receptor activation mediates copper homeostasis in hippocampal neurons. J. Neurosci. 25, 239-246. doi: 10.1523/JNEUROSCI.3699-04.2005

Schlief, M. L., and Gitlin, J. D. (2006). Copper homeostasis in the CNS: a novel link between the NMDA receptor and copper homeostasis in the hippocampus. Mol. Neurobiol. 33, 81-90. doi: 10.1385/mn:33:2:81

Selkoe, D. J. (2011). Alzheimer's disease. Cold Spring Harb. Perspect. Biol. 3:a004457. doi: 10.1101/cshperspect.a004457

Selkoe, D. J., and Hardy, J. (2016). The amyloid hypothesis of Alzheimer's disease at 25 years. EMBO Mol. Med. 8, 595-608. doi: 10.15252/emmm. 201606210

Sensi, S. L., Paoletti, P., Bush, A. I., and Sekler, I. (2009). Zinc in the physiology and pathology of the CNS. Nat. Rev. Neurosci. 10, 780-791. doi: 10.1038/nrn2734

Sensi, S. L., Paoletti, P., Koh, J. Y., Aizenman, E., Bush, A. I., and Hershfinkel, M. (2011). The neurophysiology and pathology of brain zinc. J. Neurosci. 31, 16076-16085. doi: 10.1523/JNEUROSCI.3454-11.2011

Siddiqui, T. J., and Craig, A. M. (2011). Synaptic organizing complexes. Curr. Opin. Neurobiol. 21, 132-143. doi: 10.1016/j.conb.2010.08.016

Smith, D. G., Cappai, R., and Barnham, K. J. (2007). The redox chemistry of the Alzheimer's disease amyloid $\beta$ peptide. Biochim. Biophys. Acta 1768, 1976-1990. doi: 10.1016/j.bbamem.2007.02.002

Smith, D. P., Smith, D. G., Curtain, C. C., Boas, J. F., Pilbrow, J. R., Ciccotosto, G. D., et al. (2006). Copper-mediated amyloid- $\beta$ toxicity is associated with an intermolecular histidine bridge. J. Biol. Chem. 281, 15145-15154. doi: 10.1074/jbc.m600417200

Soba, P., Eggert, S., Wagner, K., Zentgraf, H., Siehl, K., Kreger, S., et al. (2005). Homo- and heterodimerization of APP family members promotes intercellular adhesion. EMBO J. 24, 3624-3634. doi: 10.1038/sj.emboj.7600824

Spoerri, L., Vella, L. J., Pham, C. L., Barnham, K. J., and Cappai, R. (2012). The amyloid precursor protein copper binding domain histidine residues 149 and 151 mediate APP stability and metabolism. J. Biol. Chem. 287, 26840-26853. doi: 10.1074 /jbc.m112.355743

Steiner, H., Fluhrer, R., and Haass, C. (2008). Intramembrane proteolysis by $\gamma$-secretase. J. Biol. Chem. 283, 29627-29631. doi: 10.1074/jbc.R800010200

Südmeyer, M., Saleh, A., Wojtecki, L., Cohnen, M., Gross, J., Ploner, M., et al. (2006). Wilson's disease tremor is associated with magnetic resonance imaging lesions in basal ganglia structures. Mov. Disord. 21, 2134-2139. doi: $10.1002 / \mathrm{mds} .21136$

Talmard, C., Guilloreau, L., Coppel, Y., Mazarguil, H., and Faller, P. (2007). Amyloid-beta peptide forms monomeric complexes with $\mathrm{Cu}$ (II) and $\mathrm{Zn}$ (II) prior to aggregation. Chembiochem 8, 163-165. doi: 10.1002/cbic.200600319

Tamano, H., and Takeda, A. (2011). Dynamic action of neurometals at the synapse. Metallomics 3, 656-661. doi: 10.1039/c1mt00008j

Thinakaran, G., and Koo, E. H. (2008). Amyloid precursor protein trafficking, processing and function. J. Biol. Chem. 283, 29615-29619. doi: 10.1074/jbc. r800019200

Tiiman, A., Palumaa, P., and Tõugu, V. (2013). The missing link in the amyloid cascade of Alzheimer's disease-metal ions. Neurochem. Int. 62, 367-378. doi: 10.1016/j.neuint.2013.01.023

Tõugu, V., Tiiman, A., and Palumaa, P. (2011). Interactions of $\mathrm{Zn}(\mathrm{II})$ and $\mathrm{Cu}(\mathrm{II})$ ions with Alzheimer's amyloid-beta peptide. Metal ion binding, contribution to fibrillization and toxicity. Metallomics 3, 250-261. doi: 10.1039/c0mt00073f

Treiber, C., Simons, A., Strauss, M., Hafner, M., Cappai, R., Bayer, T. A., et al. (2004). Clioquinol mediates copper uptake and counteracts copper efflux activities of the amyloid precursor protein of Alzheimer's disease. J. Biol. Chem. 279, 51958-51964. doi: 10.1074/jbc.M407410200
Turski, M. L., and Thiele, D. J. (2009). New roles for copper metabolism in cell proliferation, signaling, and disease. J. Biol. Chem. 284, 717-721. doi: 10. 1074/jbc.r800055200

Tyan, S. H., Shih, A. Y., Walsh, J. J., Maruyama, H., Sarsoza, F., Ku, L., et al. (2012). Amyloid precursor protein (APP) regulates synaptic structure and function. Mol. Cell. Neurosci. 51, 43-52. doi: 10.1016/j.mcn.2012. 07.009

Vulpe, C., Levinson, B., Whitney, S., Packman, S., and Gitschier, J. (1993). Isolation of a candidate gene for Menkes disease and evidence that it encodes a copper-transporting ATPase. Nat. Genet. 3, 7-13. doi: 10.1038/ng 0193-7

Walsh, D. M., Minogue, A. M., Sala Frigerio, C., Fadeeva, J. V., Wasco, W., and Selkoe, D. J. (2007). The APP family of proteins: similarities and differences. Biochem. Soc. Trans. 35, 416-420. doi: 10.1042/bst0350416

Watt, N. T., Whitehouse, I. J., and Hooper, N. M. (2010). The role of zinc in Alzheimer's disease. Int. J. Alzheimers Dis. 2011:971021. doi: 10.4061/2011/971021

Weiser, T., and Wienrich, M. (1996). The effects of copper ions on glutamate receptors in cultured rat cortical neurons. Brain Res. 742, 211-218. doi: 10.1016/s0006-8993(96)01009-8

Weyer, S. W., Klevanski, M., Delekate, A., Voikar, V., Aydin, D., Hick, M., et al. (2011). APP and APLP2 are essential at PNS and CNS synapses for transmission, spatial learning and LTP. EMBO J. 30, 2266-2280. doi: 10.1038/emboj.2011.119

Weyer, S. W., Zagrebelsky, M., Herrmann, U., Hick, M., Ganss, L., Gobbert, J., et al. (2014). Comparative analysis of single and combined APP/APLP knockouts reveals reduced spine density in APP-KO mice that is prevented by APPs $\alpha$ expression. Acta Neuropathol. Commun. 2:36. doi: 10.1186/2051-59602-36

White, A. R., Du, T., Laughton, K. M., Volitakis, I., Sharples, R. A., Xilinas, M. E., et al. (2006). Degradation of the Alzheimer disease amyloid beta-peptide by metal-dependent up-regulation of metalloprotease activity. J. Biol. Chem. 281, 17670-17680. doi: 10.1074/jbc.m602487200

White, A. R., Reyes, R., Mercer, J. F., Camakaris, J., Zheng, H., Bush, A. I., et al. (1999). Copper levels are increased in the cerebral cortex and liver of APP and APLP2 knockout mice. Brain Res. 842, 439-444. doi: 10.1016/s00068993(99)01861-2

Willem, M., Tahirovic, S., Busche, M. A., Ovsepian, S. V., Chafai, M., Kootar, S., et al. (2015). $\eta$-Secretase processing of APP inhibits neuronal activity in the hippocampus. Nature 526, 443-447. doi: 10.1038/nature14864

Winkler, E., Julius, A., Steiner, H., and Langosch, D. (2015). Homodimerization protects the amyloid precursor protein C99 fragment from cleavage by $\gamma$-secretase. Biochemistry 54, 6149-6152. doi: 10.1021/acs.biochem. 5 b00986

You, H., Tsutsui, S., Hameed, S., Kannanayakal, T. J., Chen, L., Xia, P., et al. (2012). A $\beta$ neurotoxicity depends on interactions between copper ions, prion protein and N-methyl-D-aspartate receptors. Proc. Natl. Acad. Sci. U S A 109, 1737-1742. doi: 10.1073/pnas.1110789109

Zeng, L., Miller, E. W., Pralle, A., Isacoff, E. Y., and Chang, C. J. (2006). A selective turn-on fluorescent sensor for imaging copper in living cells. J. Am. Chem. Soc. 128, 10-11. doi: 10.1021/ja055064u

Zou, C., Crux, S., Marinesco, S., Montagna, E., Sgobio, C., Shi, Y., et al. (2016). Amyloid precursor protein maintains constitutive and adaptive plasticity of dendritic spines in adult brain by regulating D-serine homeostasis. EMBO J. 35, 2213-2222. doi: 10.15252/embj.201694085

Conflict of Interest Statement: The authors declare that the research was conducted in the absence of any commercial or financial relationships that could be construed as a potential conflict of interest.

Copyright (c) 2017 Wild, August, Pietrzik and Kins. This is an open-access article distributed under the terms of the Creative Commons Attribution License (CC BY). The use, distribution and reproduction in other forums is permitted, provided the original author(s) or licensor are credited and that the original publication in this journal is cited, in accordance with accepted academic practice. No use, distribution or reproduction is permitted which does not comply with these terms. 